\title{
The significance of Howell-Jolly bodies and giant metamyelocytes in marrow smears
}

\author{
D. W. DAWSON AND H. P. R. BURY ${ }^{1}$ \\ From the Department of Pathology, Crumpsall Hospital, Manchester
}

SYNOPSIS Howell-Jolly bodies in erythroid precursors can be found in the marrow in a variety of diseases. More than $1 \%$ in the later erythroblasts is rarely found except in vitamin $B_{12}$ or folic acid deficiency states.

Giant metamyelocytes are probably always the result of vitamin $B_{12}$ or folic acid deficiency A distinction is drawn between the deficiency of, and therapeutic need for, vitamin $\mathbf{B}_{\mathbf{1 2}}$ and folic acid음

The detection of vitamin $\mathbf{B}_{12}$ or folic acid deficiency is often difficult, sometimes impossible, by examining marrow alone, particularly if the alteration in the nuclear pattern of the erythroblasts is the only pathology on which the diagnosis is to be made. Cox, Matthews, Meynell, Cooke, and Gaddie (1960) refer to the many reports of patients with vitamin $B_{12}$ deficiency and normoblastic erythropoiesis. Where methods of vitamin $B_{12}$ and folic acid estimation are available the interpretation of ambiguous erythropoiesis may assume less importance, but these procedures are not yet suitable for routine hospital work. The report of Hutchison and Ferguson-Smith (1959) on the correlation between Howell-Jolly bodies in red cell precursors and vitamin $B_{12}$ or folic acid deficiency is thus of importance, but we considered it advisable to confirm their findings, especially in cases where the type of erythropoiesis was difficult to interpret. At the same time we decided to follow Lehmann's (1955) suggestion and review the significance of giant metamyelocytes in the marrow.

Other features generally considered to be associated with a megaloblastic change are premature haemoglobinization and a maturation arrest of the erythroblasts. The former is a most subjective assessment and may be valueless in the presence of concomitant iron deficiency, and was therefore not considered. The degree of maturation arrest had to be taken into account when determining the significance of Howell-Jolly bodies and the value of this feature is also discussed.

'Present address: Children's Hospital, Sheffield, 10.

Received for publication 1 November 1960.
MATERIALS AND METHODS

Marrow smears from the following conditions (numbers of cases in brackets) were examined.

GROUP I CONDITIONS RESPONDING TO VITAMIN B B $_{12}$ O\& FOLIC ACID Pernicious anaemia (45), post-gastrectom anaemia (5), malabsorption syndrome (5), nutritional $B_{1}$ deficiency (1), leukaemia with megaloblastic anaemia (2), and anticonvulsant macrocytic anaemia (6). Marrow examinations were made on these patients before the start of treatment, and, in addition, 12 patients witb megaloblastic anaemia under treatment were investigate

GROUP II CONDITIONS WITHOUT APPARENT $\mathrm{B}_{12}$, FOLI ACID, OR IRON DEFICIENCY Leukaemia (10), other myelos proliferative disorders (12), carcinoma (8), thrombo cytopenic purpura (8), chronic infection (7), refractoris normoblastic anaemia (3), cirrhosis (3), haemolytio anaemia (2), various miscellaneous disorders (7), an normal (8). There were 22 cases of iron-deficiency anaemia not following upon a gastrectomy.

The features assessed in each smear were (1) the pero centage of erythroid precursors earlier than the interv mediate stage of development. Three hundred erythroblasts were counted and the percentage calculated to thes nearest whole number; (2) the number of Howell-Jolles bodies in 500 erythroblasts, and the presence of two of more Howell-Jolly bodies in any of these erythroid precursors. Howell-Jolly bodies were not seen in cerfor earlier than the intermediate stage of developmene Therefore, because of the varying degree of maturation arrest in the two groups, the counts were corrected using the percentage of erythroid precursors to give the percentage of Howell-Jolly bodies in the intermediato or late erythroblasts. Cells in mitosis were exclude from the counts in Nos. 1 and 2 above. (3) The type of erythropoiesis, as judged on 500 cells, was classified as normoblastic, megaloblastic if any cell showed the 
characteristic nuclear change, and transitional megaloblastic if any cell showed a transformation towards a megaloblast but none had reached this degree of abnormality. (4) Cells of the metamyelocyte or stab stage larger than $18 \mu$ were counted as giant metamyelocytes. They were searched for under a high-power objective in squash preparations of marrow particles giving highly cellular fields. Their frequency in the smears was recorded as follows:-

$0=$ none in whole smear

$+=1$ to 5 in whole smear

$++=$ several in whole smear, but less than one per four fields

$++t=1$ or more per four fields

\section{RESULTS}

The findings in group I (excluding cases under treatment) and group II are presented in Table I.

\section{TABLE I}

INCIDENCE OF HOWELL-JOLLY BODIES, GIANT METAMYELOCYTES, AND ERYTHROID PRECURSORS IN CASES WITH (GROUP I) AND WITHOUT (GROUP II) APPARENT VITAMIN $B_{12}$ OR FOLIC ACID DEFICIENCY

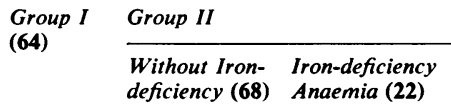

Without Iron- Iron-deficiency deficiency (68) Anaemia (22)

Howell-Jolly bodies ( $\%)$

0
1
$1-2$
$2-3$
$3+$

$\begin{array}{rrr}0 & 39 & 5 \\ 3 & 25 & 12 \\ 6 & 2 & 2 \\ 7 & 1 & 2 \\ 48 & 1 & 1\end{array}$

Smears showing erythro-

blasts containing multiple
Howell-Jolly bodies

60

Giant metamyelocytes

Erythroid precursors (\%)

$\begin{array}{crrr}\text { Giant metamyelocytes } & & & 12 \\ 0 & 2 & 64 & 7 \\ + & 15 & 3 & 2 \\ ++ & 26 & 0 & 1 \\ +++ & 21 & 0 & \\ & & & 18 \\ \text { Erythroid precursors }(\%) & & 62 & 4 \\ \text { Normal } & 17 & 6 & \end{array}$

$\begin{array}{crrr}\text { Giant metamyelocytes } & & & 12 \\ 0 & 2 & 64 & 7 \\ + & 15 & 3 & 2 \\ ++ & 26 & 0 & 1 \\ +++ & 21 & 0 & \\ & & & 18 \\ \text { Erythroid precursors }(\%) & & 62 & 4 \\ \text { Normal } & 17 & 6 & \end{array}$

5

12

2

1

Figures under groups refer to number of cases.

HOWELL-JOLLY BODIES In group 1, Howell-Jolly bodies were found in every smear. In $96 \%$ there were $1 \%$ or more, and cells containing two or more bodies were found in $94 \%$. In contrast, although $50 \%$ of the cases in group II contained Howell-Jolly bodies, only $10 \%$ had over $1 \%$ and $8 \%$ had multiple bodies in any cell. The highest counts of HowellJolly bodies were in group I, $32.4 \%$, and in group II, $5.4 \%$. The degree of anaemia did not account for the difference in findings between the two groups. In group II there was no correlation between the presence or the number of Howell-Jolly bodies and the severity of the anaemia whereas in group I there was a relationship, although it was not close. Separating the cases according to size of the HowellJolly bodies gave no useful information.

There was no significant difference in the percentage of Howell-Jolly bodies between those conditions in group $I$ that responded to $B_{12}$ and those that responded to folic acid (six anticonvulsant macrocytic anaemias, three malabsorption syndrome, two leukaemias).

Among the eight normal marrows, Howell-Jolly bodies were found in three, though each had less than $1 \%$. In none were multiple bodies present.

GIANT METAMYelocytes In group I giant metamyelocytes were found in $97 \%$ of cases, and in large numbers $(++$ or +++$)$ in $73 \%$. They were not seen in two cases. In group II they were seen in $14 \%$ of the cases, and in large numbers in $3 \%$. The three cases of group II without iron deficiency in which giant metamyelocytes were seen were two with chronic infections and one with acute myeloid leukaemia. No giant metamyelocytes were seen in the normal marrow smears.

The more severely anaemic patients in group I usually had the more numerous giant metamyelocytes, but, as with Howell-Jolly bodies, the correlation between the degree of anaemia and numbers found was not close. There was no such correlation in the group II cases in which they were present. There was no difference in the frequency of giant metamyelocytes between the cases which responded to $B_{12}$ and those which responded to folic acid.

PERCENTAGE OF ERYTHROID PRECURSORS From previous experience a figure of up to $9 \%$ for this finding was considered to be normal. The eight normal cases in group II fell below this level. In group I, $73 \%$ and in group II, $11 \%$ showed an increase in the proportion of erythroid precursors: the highest percentage in group I was $\mathbf{5 0}$ and in group II 37 . In group I there was a fairly close correlation between the percentage of erythroid precursors and the severity of the anaemia.

From these results the features suggestive but not diagnostic of $\mathrm{B}_{12}$ or folic acid deficiency appeared to be $1 \%$ or more cells containing Howell-Jolly bodies or multiple bodies in any erythroblast; several giant metamyelocytes in smear $(++$ or more $) ; 10 \%$ or more early erythroid precursors.

Of the 19 cases in group II with one or more of these features, 18 were not considered to be deficient in vitamin $B_{12}$ or folic acid for the following reasons: Ten cases (nine iron-deficiency anaemias and one pyridoxine-responsive anaemia) responded promptly and completely to appropriate therapy without 
administration of vitamin $\mathbf{B}_{12}$ or folic acid. Three cases (two refractory normoblastic anaemias and one pre-leukaemic leukaemia) did not respond to vitamin $\mathbf{B}_{12}$ or folic acid. Five cases (one each of congestive cardiac failure, cirrhosis, idiopathic acquired haemolytic anaemia, Hodgkin's disease, and polycythaemia rubra vera) gave no clinical or haematological indications of vitamin $B_{12}$ or folic acid deficiency during the subsequent course of their disease. One patient with acute myeloid leukaemia (a smear showed $1.4 \%$ and multiple Howell-Jolly bodies) died soon after marrow puncture and therefore without adequate follow-up. In this case a deficiency of vitamin $B_{12}$ or folic acid cannot be excluded with certainty.

\section{APPLICATION OF RESULTS TO DIFFICULT MARROWS}

Supportive evidence of vitamin $\mathbf{B}_{\mathbf{1 2}}$ or folic acid deficiency in the marrow smear is only needed in cases where the megaloblastic transformation is absent or incomplete. The value of this evidence can only be judged if it is of assistance in such instances, and the cases without frankly megaloblastic marrows in group $I$ were therefore considered separately (Table II). In the 23 cases $1 \%$ or more Howell-Jolly bodies were present in 21 , multiple Howell-Jolly bodies in 16, giant metamyelocytes ( ++ or more) in 14 , and the percentage of erythroid precursors increased in eight. One or more of these changes were, however, present in every case.
The problem of the investigation of an anaemia after vitamin $B_{12}$ or folic acid has been given to the patient is not infrequent. Return of megaloblastic to normoblastic erythropoiesis is rapid and corrobora-tive evidence of previous vitamin $\mathrm{B}_{\mathbf{1 2}}$ or folic acid deficiency persisting after the erythroblastic reversion would be valuable. To determine how long the abnormalities considered here remain after treatment a series of marrows taken at varying times afters the start of vitamin $B_{12}$ or folic acid therapy was $\vec{D}$ examined (Table III). The persistence of supportive evidence might depend on the degree of initiats change and the pre-treatment findings in the eight cases in which they were available are also shown? There is an insufficient number of cases from which $\vec{A}$ to draw definite conclusions. Cases 10 and 11 mayp have received suboptimal therapy and the results may thus be misleading. In the others, after erythropoiesis was no longer frankly megaloblastic, Howell-? Jolly bodies and the percentage of erythroid pre ${ }_{-}$ cursors were still abnormal in two, and giant meta myelocytes in three (with an occasional one in threemore).

\section{IRON-DEFIENCY ANAEMIA}

Originally all the cases in group II were considered together but it was noticed that many of them show: ing the features suggestive of vitamin $B_{12}$ or folic aciß口 deficiency were cases of iron-deficiency anaemia $\overrightarrow{0}$ Smears from patients with this disease were therefore

TABLE II

TWENTY-THREE CASES WITHOUT FRANKLY MEGALOBLASTIC MARROWS RESPONDING TO VITAMIN $B_{12}$ OR FOLIC ACID THERAPY

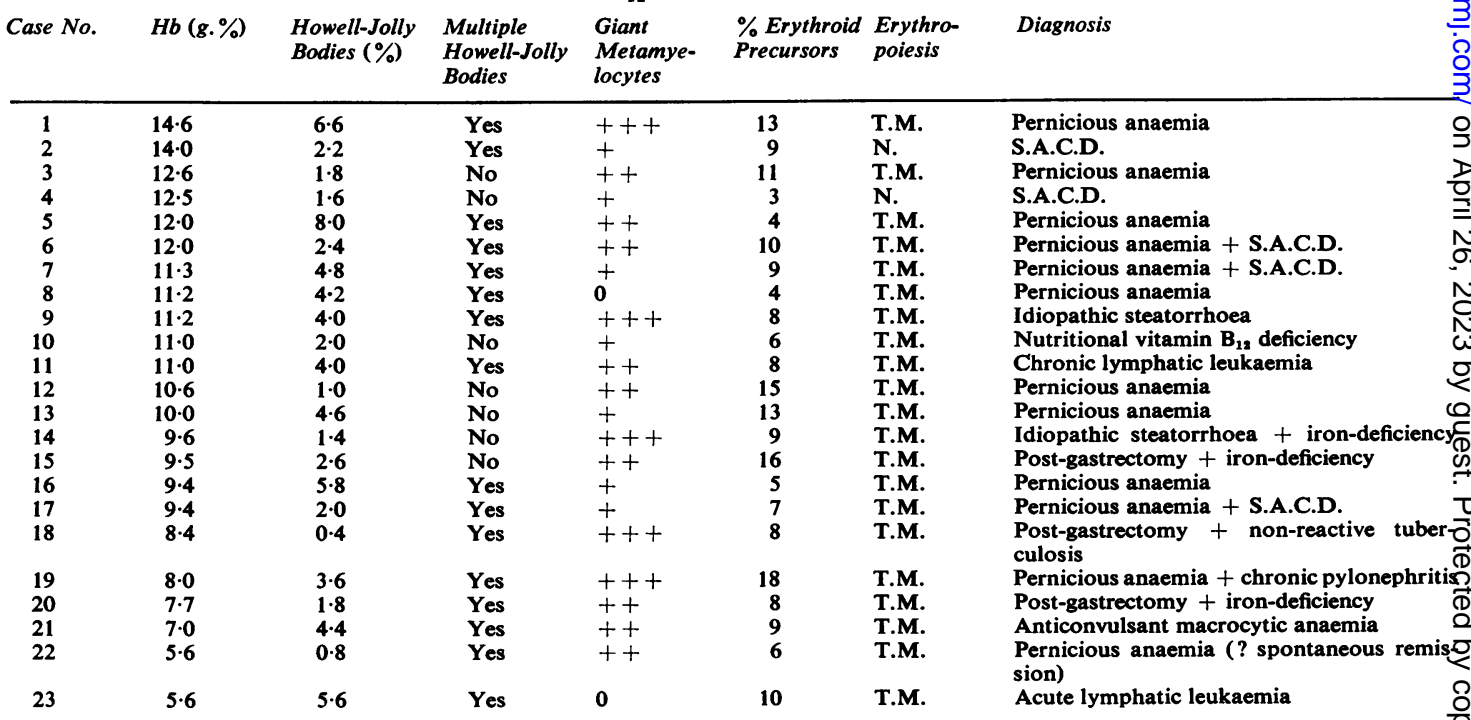


recorded separately in Table $\mathrm{I}$, and those with giant metamyelocytes, excess Howell-Jolly bodies, or a raised percentage of erythroid precursors in more detail in Table IV. These 12 showed no constant features either in their marrow findings or clinical data, and in the latter respect did not differ from the 10 whose marrows had no evidence suggestive of vitamin $\mathrm{B}_{12}$ or folic acid deficiency.

\section{SPLENECTOMY}

Because of the known relationship between HowellJolly bodies in the circulating erythrocytes and splenectomy, the opportunity was taken to examine certain post-splenectomy marrows. Three patients had undergone splenectomy during upper abdominal operations two to three weeks previously. In each smear Howell-Jolly bodies were present, but less than $1 \%$ in number, and in none were they multiple. Two patients who now presented with pernicious anaemia had undergone splenectomy six and eight years ago during repair of hiatus hernia and for traumatic rupture. They showed $9.0 \%$ and $5.4 \%$ Howell-Jolly bodies, and both had cells with multiple bodies. These percentages were of the same order as the figures recorded in patients with pernicious

TABLE III

MARROW FINDINGS IN 12 PATIENTS RESPONDING TO VITAMIN B 12 OR FOLIC ACID

\begin{tabular}{|c|c|c|c|c|c|c|c|c|c|c|c|c|c|c|}
\hline $\begin{array}{l}\sum^{\circ} \\
\text { ż }\end{array}$ & 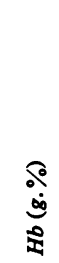 & 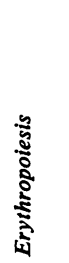 & 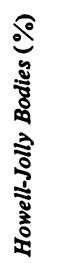 & 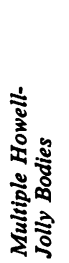 & 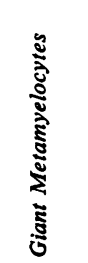 & 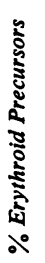 & 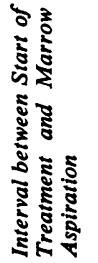 & 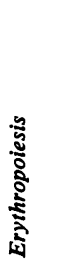 & 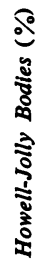 & 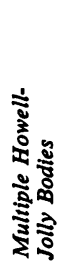 & 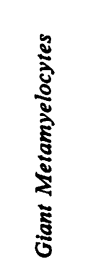 & 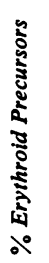 & & \\
\hline $\begin{array}{r}24 \\
25 \\
26 \\
27 \\
28 \\
29 \\
6 \\
30 \\
31 \\
32 \\
10\end{array}$ & $\begin{array}{r}5 \cdot 6 \\
4 \cdot 6 \\
4.6 \\
7.2 \\
4.9 \\
5.6 \\
12.0 \\
7.0 \\
7.0 \\
7.0 \\
11.0\end{array}$ & $\begin{array}{l}\frac{M}{M} \\
\overline{\mathbf{M}} \\
\overline{-} \\
\overline{\text { T.M. }} \\
\mathbf{M} \\
\mathbf{M} \\
\mathbf{M} \\
\text { T.M. }\end{array}$ & $\begin{array}{l}32 \cdot 4 \\
\overline{7} \\
7 \cdot 2 \\
- \\
\bar{Z} \\
2 \cdot 4 \\
5 \cdot 0 \\
0 \cdot 8 \\
16 \cdot 8 \\
2 \cdot 0\end{array}$ & $\begin{array}{l}\text { Yes } \\
\overline{\text { Yes }} \\
\overline{-} \\
\overline{-} \\
\text { Yes } \\
\text { Yes } \\
\text { Yes } \\
\text { Yes } \\
\text { No }\end{array}$ & $\begin{array}{l}+++ \\
+++ \\
= \\
= \\
++ \\
+++ \\
++ \\
++ \\
+\end{array}$ & $\begin{array}{l}\frac{25}{26} \\
\frac{-}{7} \\
10 \\
31 \\
15 \\
11 \\
6\end{array}$ & $\begin{array}{r}15 \frac{1}{2} \text { hrs. } \\
22 \text { hrs. } \\
3 \text { days } \\
5 \text { days } \\
8 \text { days } \\
10 \text { days } \\
14 \text { days } \\
14 \text { days } \\
15 \text { days } \\
18 \text { days } \\
21 \text { days }\end{array}$ & $\begin{array}{l}\mathbf{M} \\
\mathbf{M} \\
\mathbf{N} \\
\mathbf{T} . \mathbf{M} . \\
\text { T.M. } \\
\mathbf{N} \\
\mathbf{N} \\
\mathbf{N} \\
\mathbf{N} \\
\mathbf{N} \\
\mathbf{N}\end{array}$ & $\begin{array}{r}32.8 \\
4.2 \\
0.8 \\
6.2 \\
0.8 \\
0.2 \\
\overline{0.2} \\
\overline{-} \\
\overline{1.4}\end{array}$ & $\begin{array}{l}\text { Yes } \\
\text { Yes } \\
\text { Yes } \\
\text { Yes } \\
\text { No } \\
\text { No } \\
\text { No } \\
\text { No } \\
\text { No } \\
\text { No } \\
\text { Yes }\end{array}$ & $\begin{array}{l}+++ \\
+++ \\
+++ \\
++ \\
++ \\
+ \\
+ \\
0 \\
+ \\
0 \\
0\end{array}$ & $\begin{array}{r}21 \\
43 \\
6 \\
9 \\
16 \\
3 \\
4 \\
6 \\
6 \\
10 \\
8 \\
6\end{array}$ & $\begin{array}{l}\text { Pernicious anaemia } \\
\text { Pernicious anaemia } \\
\text { Pernicious anaemia } \\
\text { Pernicious anaemia } \\
\text { Pernicious anaemia } \\
\text { Pernicious anaemia } \\
\text { Pernicious anaemia } \\
\text { Pernicious anaemia } \\
\text { Pernicious anaemia } \\
\text { Pernicious anaemia } \\
\text { Nutritional vitamin }\end{array}$ & $\begin{array}{l}\text { Cytamen intramuscularly } \\
\text { Cytamen intramuscularly } \\
\text { Cytamen intramuscularly } \\
\text { Cytamen intramuscularly } \\
\text { Cytamen intramuscularly } \\
\text { Cytamen intramuscularly } \\
\text { Cytamen intramuscularly } \\
\text { Cytamen intramuscularly } \\
\text { Cytamen intramuscularly } \\
\text { Folic acid } \\
\text { Oral B B }\end{array}$ \\
\hline 11 & 11.0 & T.M. & $4 \cdot 0$ & Yes & ++ & 8 & 28 days & $\mathbf{N}$ & $1 \cdot 0$ & No & 0 & 5 & $\begin{array}{l}\text { B12 deticiency } \\
\text { Chromic lymphatic } \\
\text { leukaemia }\end{array}$ & Folic acid \\
\hline
\end{tabular}

TABLE IV

TWELVE CASES OF IRON-DEFICIENCY ANAEMIA RESPONDING TO IRON THERAPY WITH MARROW FINDINGS SUGGESTIVE OF VITAMIN $B_{12}$ OR FOLIC ACID DEFICIENCY

\begin{tabular}{|c|c|c|c|c|c|c|c|c|c|c|c|c|}
\hline \multirow{2}{*}{$\begin{array}{l}\text { Case } \\
\text { No. }\end{array}$} & \multirow[t]{2}{*}{$\operatorname{Sex}$} & \multirow[t]{2}{*}{ Age } & \multirow{2}{*}{$\begin{array}{l}\mathrm{Hb} \\
(\mathrm{g} . \%)\end{array}$} & \multirow{2}{*}{$\begin{array}{l}\text { M.C.H.C. } \\
(\%)\end{array}$} & \multicolumn{4}{|c|}{ Marrow Findings } & \multirow{2}{*}{$\begin{array}{l}\text { Free } \\
\text { Acid in } \\
\text { Test } \\
\text { Meal }\end{array}$} & \multirow{2}{*}{$\begin{array}{l}\text { Recent } \\
\text { Iron } \\
\text { Therapy } \\
\text { before } \\
\text { Marrow } \\
\text { Examinatio }\end{array}$} & \multirow{2}{*}{$\begin{array}{l}\text { Duration } \\
\text { of } \\
\text { Symptoms }\end{array}$} & \multirow{2}{*}{ Aetiology of Anaemia } \\
\hline & & & & & $\begin{array}{l}\text { Howell- } \\
\text { Jolly } \\
\text { Bodies }\end{array}$ & $\begin{array}{l}\text { Multiple } \\
\text { Howell- } \\
\text { Jolly } \\
\text { Bodies }\end{array}$ & $\begin{array}{l}\text { Giant } \\
\text { Metamye- } \\
\text { locytes }\end{array}$ & $\begin{array}{l}\% \\
\text { Erythroid } \\
\text { Precursors }\end{array}$ & & & & \\
\hline 69 & $\mathbf{M}$ & 64 & $10 \cdot 8$ & - & 1.0 & No & + & 4 & - & Yes & Weeks & $\begin{array}{l}\text { Peptic ulcer, chronic } \\
\text { bronchitis }\end{array}$ \\
\hline $\begin{array}{l}70 \\
72\end{array}$ & $\begin{array}{l}\mathbf{M} \\
\mathbf{F}\end{array}$ & $\begin{array}{l}66 \\
80\end{array}$ & $\begin{array}{l}9 \cdot 2 \\
8 \cdot 6\end{array}$ & $\begin{array}{l}26 \\
27\end{array}$ & $\begin{array}{l}2 \cdot 0 \\
2 \cdot 0\end{array}$ & $\begin{array}{l}\text { Yes } \\
\text { Yes }\end{array}$ & $\begin{array}{l}0 \\
+\end{array}$ & $\begin{array}{r}3 \\
10\end{array}$ & $\overline{\text { Present }}$ & $\begin{array}{l}\text { No } \\
\text { Yes }\end{array}$ & $\begin{array}{l}\text { Weeks } \\
\text { Years }\end{array}$ & $\begin{array}{l}\text { Idiopathic } \\
\text { Steatorrhoea, duodenal } \\
\text { diverticulum }\end{array}$ \\
\hline $\begin{array}{l}73 \\
74\end{array}$ & $\begin{array}{l}\mathbf{F} \\
\mathbf{M}\end{array}$ & $\begin{array}{l}83 \\
63\end{array}$ & $\begin{array}{l}8 \cdot 2 \\
8 \cdot 0\end{array}$ & $\begin{array}{l}29 \\
24\end{array}$ & $\begin{array}{l}0 \cdot 4 \\
5 \cdot 4\end{array}$ & $\begin{array}{l}\text { No } \\
\text { Yes }\end{array}$ & $\begin{array}{l}+++ \\
+\end{array}$ & $\begin{array}{r}9 \\
11\end{array}$ & - & $\begin{array}{l}\text { Yes } \\
\text { Yes }\end{array}$ & $\begin{array}{l}\text { Months } \\
\text { Weeks }\end{array}$ & $\begin{array}{l}\text { Hiatus hernia } \\
\text { Peptic ulcer, chronic } \\
\text { bronchitis }\end{array}$ \\
\hline $\begin{array}{l}75 \\
77 \\
78 \\
79 \\
81 \\
84 \\
89\end{array}$ & $\begin{array}{l}\mathbf{F} \\
\mathbf{M} \\
\mathbf{F} \\
\mathbf{F} \\
\mathbf{F} \\
\mathbf{F} \\
\mathbf{M}\end{array}$ & $\begin{array}{l}72 \\
40 \\
33 \\
45 \\
52 \\
46 \\
59\end{array}$ & $\begin{array}{l}7 \cdot 4 \\
6 \cdot 8 \\
6 \cdot 4 \\
5 \cdot 8 \\
5 \cdot 8 \\
5 \cdot 5 \\
3 \cdot 6\end{array}$ & $\begin{array}{l}27 \\
24 \\
-22 \\
- \\
-\end{array}$ & $\begin{array}{l}0.6 \\
0.2 \\
0.2 \\
0.6 \\
0.2 \\
1 \cdot 2 \\
0.2\end{array}$ & $\begin{array}{l}\text { No } \\
\text { No } \\
\text { No } \\
\text { No } \\
\text { No } \\
\text { No } \\
\text { No }\end{array}$ & $\begin{array}{l}+ \\
+ \\
++ \\
+ \\
++ \\
+ \\
+\end{array}$ & $\begin{array}{r}6 \\
6 \\
9 \\
7 \\
7 \\
17 \\
2 \\
10\end{array}$ & $\begin{array}{l}-\overline{\text { Absent }} \\
\text { Present } \\
\text { Absent } \\
\text { Present } \\
\overline{\text { Absent }}\end{array}$ & $\begin{array}{l}\text { Yes } \\
\text { Yes } \\
\text { No } \\
\text { No } \\
\text { No } \\
\text { Yes } \\
\text { No }\end{array}$ & $\begin{array}{l}\text { Years } \\
\text { Years } \\
\text { Weeks } \\
\text { Years } \\
\text { Years } \\
\text { Months } \\
\text { Months }\end{array}$ & $\begin{array}{l}\text { Idiopathic } \\
\text { Haemorrhoids } \\
\text { Idiopathic } \\
\text { Duodenal ulcer } \\
\text { Idiopathic } \\
\text { Menorrhagia } \\
\text { Gastric ulcer }\end{array}$ \\
\hline
\end{tabular}


anaemia with similar degrees of anaemia who had not undergone splenectomy. A sixth patient with a refractory normoblastic anaemia showed $1.0 \%$ Howell-Jolly bodies before and 0.6\% 11 months after splenectomy.

\section{DISCUSSION}

HOWELL-JOLLY BODIES IN ERYTHROID PRECURSORS Hutchison and Ferguson-Smith (1959) in a study of the significance of the presence of nuclear fragments in the erythroid precursors considered it probable that disordered nucleic acid synthesis resulting from vitamin $B_{12}$ or folic acid deficiency was the fundamental factor in their production. They did, however, record four cases in which infrequent solitary inclusions were found but in which there was no evidence of vitamin deficiency, and they thought that the bodies were possibly artefacts. They also found similar inclusions in one case of iron-deficiency anaemia.

It might be argued that the inclusions found in our cases without vitamin deficiency were not in fact Howell-Jolly bodies, but this we think unlikely. Inclusions were only counted if they were of the same degree of staining as the nucleus of the parent cell. Often in grossly megaloblastic marrows the bodies show the same reticulation as the cell nucleus. Pappenheimer bodies for which they might be mistaken are usually of a lighter hue than the nucleus and occur often in greater numbers in one cell than Howell-Jolly bodies (other than in grossly megaloblastic cells). Howell-Jolly bodies are not refractile, a feature which distinguishes them from some artefacts. In megaloblastic cells in which there were many bodies of all sizes, the small ones were identical to the inclusions found in scanty numbers in nonvitamin deficiency cases.

Since occasional Howell-Jolly bodies occur in normal marrows and in conditions in which deficiency of $\mathrm{B}_{12}$ or folic acid can be excluded, a quantitative assessment of their presence would appear to be essential if the finding is to be of value when most needed. This count takes only a few minutes to perform and at the same time permits an accurate assessment of erythropoiesis. Where erythropoiesis is obviously megaloblastic a Howell-Jolly count is of course superfluous.

Our findings show that a count of less than $1 \%$ of Howell-Jolly bodies has no significance as regards the aetiology of the anaemia, but that more than this number or the presence of multiple bodies in one cell is highly suggestive but not pathognomonic of vitamin $B_{12}$ or folic acid deficiency. The value of the finding of excess Howell-Jolly bodies in difficult marrow smears is shown in the selected cases of

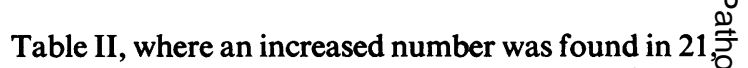
and multiple bodies in 16, of the 23 smears. If assay methods of vitamin $B_{12}$ and folic acid levels are no $\overrightarrow{F_{5}}$ available, an excess number of Howell-Jolly bodies? is sufficient evidence to justify a therapeutic trial of vitamin $B_{12}$ or folic acid. Unfortunately, in cases where therapy has been started a search for Howell Jolly bodies is of little value since they rapidly dis $\frac{0}{0}$ appear with the conversion of erythropoiesis.

GIANT METAMYLELOCYTES The literature on the specificity of giant metamyelocytes is conflicting $\omega_{\sigma}^{\omega}$ Whitby and Britton (1957) quote Henning (1935) toक the effect that they are typical of pernicious anaemia but note that Jones (1943) met them in a variety of diseases. Jones, however, had found them as well as in pernicious anaemia only in diseases associated with megaloblastic transformation of the marrow, namely, achrestic anaemia, tropical macrocytic anaemia, sprue, and pernicious anaemia of prege nancy. Scott (1939) commented on their presence in one or two of 23 cases of iron-deficiency anaemia. Foy, Kondi, and Hargreaves (1950) considered themp to be as pathognomonic as megaloblasts in those anaemias which respond to liver, folic acid, Marmite or a high-protein diet. Later, Foy and Kondi (1952) reported that they were present in $20 \%$ of the maro rows of their patients with hypochromic anaemia Davidson (1954) in a survey of 500 marrows found? them associated with iron-deficiency anaemia $\overrightarrow{0}$ leukaemia, and other diseases (not stated) as well as pernicious anaemia, and Lehmann (1955) quotes? Davidson as finding giant metamyelocytes in 63 o 164 iron-deficiency anaemias. Tasker (1959) founक some abnormal myeloid cells in many normoblastic iron-deficiency anaemia marrows which responded $B$. to iron therapy. MacIver and Back (1960), on the other hand, stated that they had never seen abnormas myeloid cells in iron-deficiency anaemia.

Because of these differing reports which sugges? that giant metamyelocytes might not be confined to vitamin $\mathrm{B}_{12}$ or folic acid deficiency, we made quantitative assessment of their presence in thes marrow smears. This showed a definite relationship between the presence of many giant metamyelocytesu and the deficiency of one of the vitamins. The threes iron-deficiency anaemias containing many giank metamyelocytes would seem to refute this relation ship, but this is not necessarily so since the work of? Cox et al. (1960) and Cox, Meynell, Gaddie, and Cooke (1959) provides evidence of tissue deficiency if vitamin $B_{12}$ in apparently straightforward iron $\underset{\oplus}{\triangle}$ deficiency anaemia. Their cases responded satis factorily to iron therapy alone, as ours did.

It appears therefore that the findings of frequent? giant mctamyelocytes is, in most cases, an indicatiore 
for vitamin $B_{12}$ or folic acid therapy. Foy et al. (1950) and MacIver and Back (1960) have reported the response to folic acid of normoblastic anaemias with giant metamyelocytes though the frequency of such cells was not recorded. We have met several normoblastic anaemias in pregnancy with numerous giant metamyelocytes which responded to folic acid.

The value of finding numerous giant metamyelocytes in difficult smears appears to be less than that of Howell-Jolly bodies since only 14 of the 23 cases listed in Table II had such numbers but this is still a sufficiently common finding to make their assessment of value. But their absence does not exclude the possibility that the anaemia will respond to vitamin $\mathrm{B}_{12}$ or folic acid (Cases 8 and 23, Table II).

In cases already on vitamin therapy the number of giant metamyelocytes like Howell-Jolly bodies rapidly declines, although marrows eight days after the start of treatment may still contain many and an occasional one may be found two weeks later (Table III). These times are somewhat longer than the survival of giant metamyelocytes recorded by Leitner (1949).

Davidson (1952) commented that in iron-deficiency anaemia the giant metamyelocytes had nuclei almost, if not quite, as complicated as those associated with pernicious anaemia. Our impression was that regardless of the aetiology of the anaemia the more bizarre forms were found in those marrows with numerous giant metamyelocytes but in a few instances even the occasional one had an abnormal nucleus and is probably evidence of tissue depletion of vitamin $B_{12}$ or folic acid. It is significant that of the 25 cases recorded here with occasional giant metamyelocytes, 15 responded to $B_{12}$ or folic acid (two of these were normoblastic anaemias) and the other 10 were of iron-deficiency anaemia (see below) or had active myeloid marrows. It may be that in cases with increased myeloid activity this cell series, rather than the erythroid mass, would show the first overt signs of deficiency of $\mathrm{B}_{12}$ or folic acid. Spray and Witts (1953) have shown that patients with leukaemia appear to require abnormally large amounts of folic acid, though this is not a constant finding. Swendseid, Swanson, Meyers, and Bethell (1952) suggested that the folic acid depletion in leukaemia results from the production of large numbers of immature white cells of high folic acid content.

PERCENTAGE OF ERYTHROID PRECURSORS An arrest in maturation of the erythroid precursors was only prominent in frankly megaloblastic anaemias in group I, and as an aid to the diagnosis of difficult cases it is of little value. This is in accord with the experience of others (de Gruchy, 1958).
IRON-DEFICIENCY ANAEMIA The literature on giant metamyelocytes in iron-deficiency anaemia has been reviewed above. Our results support the findings of those authors who have recorded them to be a common occurrence in iron-deficiency anaemia. An increase in Howell-Jolly bodies is also not uncommon and is probably of similar significance, although it is not clear why the two abnormalities were not always present together. Of interest in this connexion is an analysis of the cases of vitamin $B_{12}$ or folic acid deficiency in Table II, in which it is seen that the highest percentage was not necessarily associated with the most numerous giant metamyelocytes.

The finding of Cox et al. $(1959,1960)$ of low serum and marrow $B_{12}$ levels in iron-deficiency anaemia has already been cited. There have also been reports of folic acid depletion in this disease (Spray and Witts, 1953; Chanarin, Mollin, and Anderson, 1958). We believe that the abnormal findings in our cases are the morphological results of one or more of these deficiencies. It is not our purpose to consider the possible ways in which iron deficiency may produce deficiency of $\mathrm{B}_{12}$ or folic acid but merely to record the frequency with which evidence of these deficiencies may be found.

The presence of such evidence in the marrow of a patient with iron-deficiency anaemia does not, however, mean that response to iron will be suboptimal or that the patient's anaemia will improve on vitamin $B_{12}$ or folic acid. This has been our experience in anaemia of pregnancy. Cox et al. (1959) have shown that the low serum $B_{12}$ level returns slowly to normal with iron therapy, further evidence of the relationship between the iron and vitamin deficiency. However, in certain circumstances, e.g., anaemias associated with gastrectomy, the malabsorption syndrome, or pregnancy, giant metamyelocytes or excess Howell-Jolly bodies may be indications of a vitamin depletion concomitant with, but not resulting from, the iron deficiency, which will persist despite iron therapy. A case we have encountered since completing this series supports this contention. A patient with hypochromic normoblastic anaemia following partial gastrectomy with a serum $B_{12}$ level of less than $50 \mu \mu \mathrm{g}$ per ml. responded partly to parenteral iron but after 17 days the marrow had become frankly megaloblastic. The original marrow contained numerous giant metamyelocytes but no excess Howell-Jolly bodies. This change in erythropoiesis following iron therapy has been mentioned previously by Giles and Shuttleworth (1958) and Tasker (1959). Therefore, although giant metamyelocytes and, usually, an excess of Howell-Jolly bodies, are evidence of $\mathrm{B}_{12}$ or folic acid deficiency, only by knowing the indications for which marrow aspiration was performed can their clinical 
significance be assessed. For example, if the patient has a mild normochromic anaemia with indeterminate erythropoiesis the finding of either abnormality is a valuable guide to the diagnosis of pernicious anaemia or related disease. On the other hand, such findings in an iron-deficiency anaemia, or in a marrow with myeloid hyperplasia, although basically due to vitamin $\mathbf{B}_{12}$ or folic acid depletion, indicate that haematological response to the appropriate therapy should be observed closely in case the vitamin deficiency should be unrelated to the primary disorder or irreversible without specific therapy.

SPLENECTOMY Our finding of Howell-Jolly bodies in the erythroid precursors in all our splenectomized cases is at variance with the report of Hutchison and Ferguson-Smith (1959). But we believe our results to be logical. If Howell-Jolly bodies were absent from the marrow in splenectomized patients one would have to postulate that the inclusions seen in the erythrocytes are the remains of the nucleus and that these cells are indeed nucleated red cells. But the regular eccentricity of Howell-Jolly bodies in the red blood cells and their much smaller size than the nuclei of the late normoblasts in the marrow, without intervening sizes being evident, does not support this idea.
We wish to thank Dr. A. Womack for the serum vitamino $B_{12}$ estimation.

\section{REFERENCES}

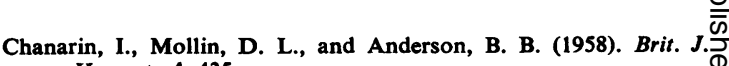
Haemat., 4, 435. Cox, E. V., Matthews, D. M., Meynell, M. J., Cooke, W. T., and $\frac{\varrho}{\mathcal{Q}}$

_- Meynell, M. J., Gaddie, R., and Cooke, W. T. (1959). Lancet, $\rightarrow$ 2, 998.

Davidson, W. M. (1952). Ibid, 1, 566

-_ (1954). Amer. J. clin. Path., 24, Suppl., p. 88.

de Gruchy, G. C. (1958). Clinical Haematology in Medical Practice, p. 113. Blackwell, Oxford.

Foy, H., and Kondi, A. (1952). Lancet, 1, 416.

,-- , and Hargreaves, A. (1950). Ibid, 1, 1172.

Giles, C., and Shuttleworth, E. M. (1958). Ibid, 2, 1341.

Henning, N. (1935). Dtsch. med. Wschr., 61, 1543. 12, 451 .

Jones, O. P. (1943). Arch. Path. (Chicago), 35, 752.

Lehmann, H. (1955). Trans. roy. Soc. trop. Med. Hyg., 49, 90.

Leitner, S. J. (1949). Bone Marrow Biopsy. English Translation from_Swiss Edition. Revised and Edited by C. J. C. Britton and E.c Neumark. Churchill, London.

MacIver, J. E., and Back, E. H. (1960). Arch. Dis. Childh., 35, 134.

Scott, R. B. (1939), Ouart. J. Med., 32 (n.s. 8), 127.

Spray, G. H., and Witts, L. J. (1953). Clin. Sci., 12, 385.

Swendseid, M. E., Swanson, A. L., Meyers, M. C., and Bethell, F. H. (1952). Blood, 7, 307.

Tasker, P. W. G. (1959). Trans. roy. Soc. trop. Med. Hyg., 53 291.

Whitby, L. E. H., and Britton, C. J. C. (1957). Disorders of the Blood 8th ed., p. 245. Churchill, London. 